\title{
The future of the church - a forgotten article of Oepke Noordmans
}

\author{
Van de Beek, Abraham \\ Stellenbosch University \\ beekavd@x4all.nl
}

\begin{abstract}
An English translation of a recovered article by the Dutch theologian Oepke Noordmans, Kerk en Toekomst (Church and future) is presented. The relevance of this article for the present context, especially in South Africa, is discussed against the background of Noordmans' theology. Noordmans is not concerned about the future of the church (which in the final analysis is not meant to last forever), but calls for participation in the Kingdom of God. Noordmans' theology is highly critical of tendencies in churches to escape from hard reality and responsibilities (Noordmans calls this weak ascesis), or to claim easily manageable solutions. He calls for a more critical attitude in accordance with the eschatological call of the Kingdom, and for a closer unity of human beings as fallible people who are united because they share a life at the foot of the cross (strong ascesis).
\end{abstract}

Key words

Noordmans; church; future; eschatology

\section{Introduction}

Oepke Noordmans (1871-1956) was one of the most outstanding Dutch theologians of the twentieth century. Though he was only a pastor in rural villages in the far north and east of the Netherlands, his work is philosophically and socially by far the most critical of his contemporary theologians. He was an erudite scholar who knew the classics of European philosophy and of Christian theology, and, though a protestant, he was also acquainted with the work of Roman Catholic theologians such as John Henry Newman. Like Karl Barth, he never gained a doctorate, but was awarded an honorary doctorate by the University of Groningen. He was twice a candidate for church professor at the University of Utrecht, but 
the Synod of the Dutch Reformed Church passed him over and appointed somebody else who was less critical.

The late Flip Theron was highly influenced by Noordmans' theology and was one of the best Noordmans specialists. He was involved in the edition of the collected works of Noordmans, which were published in twelve volumes.

Recently, Arie Oudenaarden, a retired professor of pedagogics of religion at the Christian University of Applied Sciences in Ede in the Netherlands, cleared out old papers and articles in his study. Among these were papers from the legacy of Frans Haarsma (1921-2009), a Roman Catholic professor of theology. During this process, Oudenaarden found a loose page bearing the name of Noordmans. Upon further investigation he noticed that the page was part of an article. He also succeeded in finding the other pages. It appeared to be an article from the newsletter of the congregation of the Reformed Church in Amsterdam (Noordmans 1941b), which was a reprint of an article published in the journal of the national Dutch Reformed Church in 1941 (Noordmans 1941a). Dr. Sjaak van't Kruis found the original version in the archives of the present Protestant Church in the Netherlands.

Although written more than seventy years ago in a very specific context, the article is still highly relevant, not only for the situation in the Netherlands, but also for the church in South Africa. Therefore I have decided to write an article about it in a South-African journal, not only in honour of Flip Theron, but also as a contribution to the theology of the church in the context of ongoing tensions in the churches in South Africa and their search for a viable way to the future. Dr. John Gavera made a translation of the article in English so that the text itself is accessible to a wider reading public.

\section{Noordmans' theology}

Of course, it is impossible to give an introduction into Noordmans' theology within the scope of this article. For those who are not acquainted with his work, I will nevertheless give a few pointers for a perspective on Noordmans' theology. One of his books, a volume with theological meditations on Biblical texts, is entitled Gestalte en Geest (Form and Spirit) (Noordmans 1956; VW 8: p.179-478). It is one of his later works and characteristic for his 
thought. In history events, persons, and things have continuity. People are inclined to keep to this given phenomena in order to orientate themselves in life. Noordmans labels these phenomena as "forms", gestalten. People prefer these forms, for they provide a certain degree of control. The given data of the forms are a solid base for life, for acting and trusting. These forms provided by the past are extremely important, especially in religion. We receive security from what has been given to us (cf. Van de Beek 1991). In Christian theology such forms are, for instance, the creation, the calling of Abraham, the liberation of Israel from Egypt, the messianic kingship of David, and even more so the story of Jesus and the outpouring of the Spirit on the church. We "have obtained" something in which we can place our trust. For some people this can even be the Bible as the book containing these stories that have been handed down to us. The Word of God is the solid base of our faith.

According to Noordmans, Christian faith differs from this trust in forms and given data from the past. Christian life is life in the Spirit who never gives a fixed dwelling place. On the contrary, the Spirit creates unrest, breaking down all forms in which we place our trust. The Spirit is always critical of any claim of possessing security. Therefore, the theology of Noordmans is opposed to any fixed system, institution, or attempt at imitating Christ. This does not imply that the forms of the past are unimportant. It is precisely the tension between the form and the critical Spirit, which keeps Christian life going. Without the forms, Christian life would be uncritically random in its movements. However, when based only on the forms, it would hold uncritically to the past and lose its eschatological orientation.

Two phrases, selected from two other works of Noordmans, illustrate this critical approach. The first is from his book Herschepping (Recreation) (Noordmans 1934a; VW 2: p.214-322) where he deals with the relation of creation, the cross, and the work of the Spirit. Christians are inclined to think about creation from the perspective of beautiful forms, like the roses and the forests. They think of the Creator as a good Father who provides us with food and care, all we need and who enjoys the works He made. Against this theology of creation and providence Noordmans says: "The Creator is not a Landlord ("een hereboer", "n groot plaasboer") who walks through the kingdom of providence" (Noordmans 1934a: p.62; VW 2: p.250). Creation is not about a beautiful farm, the crops that the farmer 
enjoys and the rich fruits which guarantee the future of life. Creation is a circle of light around the cross (Noordmans 1934a: p.54 =VW 2: p.245) and it is from this perspective that we should view the world. Suffering and guilt is more in accordance with reality than the success of a big farm providing a secure life. Where the light of the cross falls on created reality, we see people suffering and struggling with injustice and guilt. The idea of creation as a beautiful farm is unrealistic and serves only to close our eyes to true reality which opens up in the light of the cross.

The other phrase is from his volume of theological meditations Sinner and beggar (Zondaar en bedelaar) (Noordmans 1946b; VW 8: p.13-100). The core meditation is about the parables of the Pharisee and the tax collector and of the rich man and the poor Lazarus (Noordmans 1946b: p.9-26; VW 8: p.15-25). The Pharisee and the rich man represent those people who have a solid religious and socio-economical foundation in life. They are men of the form. They are no criminals. On the contrary, they are decent citizens. They not only feel good, they are good. The Pharisee gives his tithe and the rich man gives alms to the poor at his gate. That is why the beggar is there. That is precisely the problem, they are good: they lack any eschatological drive. Life is good as it is. They are good as they are.

Over against the Pharisee Jesus directs our eyes to the tax collector. He does not claim his moral and religious nobility. He knows himself to be just a sinner and prays for mercy. It is a well-known contrast in the church, most of all in orthodox protestant circles: we are not saved by our works but by grace alone. The conspicuous move Noordmans makes is that he keeps to this traditional interpretation, but goes two steps further. First he uncovers that Christians often abuse their confession of sin for claiming to be a good Christian. My position in the sociogram of the church improves if I speak about "amazing grace ...that saved a wretch like me". "There is a great surge of people to the assembly of the tax collectors", Noordmans writes (Noordmans 1946b: p.12; VW 8: p.17), for "nowadays every Pharisee prays with the words of the tax collector" (Noordmans 1934b: p.79; VW 2: p.115). This all fits in solid protestant theology. We are saved, not by works, whatever character that work may have, but by faith alone. Then Noordmans makes the decisive move. The parable about the rich man and Lazarus is not concerned with Lazarus' faith but with his poverty. He receives the 
award of heavenly glory because he suffered on earth and his life was not good as it was. Noordmans summarizes this by saying: "Lazarus believed with his ulcers" (Noordmans 1946b: p.18; VW 8: p.20). It is not his religious motivation which saved him, but his mere suffering on earth.

This is Noordmans in his most confronting thought. Any solid position that people construct for themselves is broken down. Even the most profound religious dogma about grace alone is surpassed. Only the suffering remains. Suffering is not a basis for anything. It is just a lack. One cannot make any claims based on ulcers. And certainly Noordmans would oppose anybody who would like to make such a claim. The real poor would make no such claims having only dogs as their friends, just as dirty as the ulcers they lick.

\section{The article}

It is against the background of this theology that we must read the recovered article. The article is very characteristic of Noordmans' thought, and maybe it is a blessing in disguise that it was not inserted into the collected works, for now it will receive special attention.

The article was written in 1941, one year after the German occupation of the Netherlands, in a time of increased oppression. People were uncertain about the future. They were also worried about the future of the church. What would happen to the national church, with its long tradition of reformed theology, under the power of a foreign, non-Christian ideology? In this context, the board of the synod of the Dutch Reformed Church, the leading church in the Netherlands at that time, published a letter to its members in order to encourage them. Christians should not be anxious about the future of the church, for God will take care of her and He calls us to participate in holding unto hope for the coming of the Kingdom of God.

It is obviously this message that motivated Noordmans to write his article. He begins with a citation from the synodical letter, written above the article as a motto. It is not so much that he opposes the message. He wants rather to give an interpretation of it. For, as is so often the case with synodical writings, they are open for many interpretations. Motivated by the synodical letter, Noordmans developed his own thought about the future of the church. 


\subsection{The church has no future}

What will be the future of the church? Noordmans' answer is surprising. He argues that finally the church will not have a future. This statement is not based on sociological investigations. It is a theological consideration. The church is not a goal in itself. God's aim for the future is not a glorious church as the most influential power in the world. On the contrary, the church is merely instrumental and only subservient to the Kingdom of God. Christ did not teach us to pray: "Let the church be everlasting", but "Your Kingdom come." The church proclaims the message of the Kingdom. The best the church can do, is to make herself superfluous: should her message be heard, the Kingdom of God will come and she will no longer be relevant.

Throughout his life, Noordmans opposed theologians and church leaders who claimed a powerful position for the church. The church must not have impressive structures and a powerful leadership. As early as in 1892, when he was a young student, he delivered a lecture about church structures and opted for a low profile church law (Noordmans 1892; VW 10: p.64-66). Later, he continuously opposed the Groningen professor, Van der Leeuw, who called for high liturgical worship as an expression of God's presence in the world in the liturgy of the church. According to Noordmans the church is nothing but a place where people are called to the Kingdom of God.

This does not mean Noordmans that opted for a free church without any order or ministry. In an early lecture he not only rejected the position of Rome with its claim of the church as a divine institution, but also the Anabaptists who rejected any order (Noordmans 1892; VW 10: p.66). His position is not a modern liberal one where Christians find their own way without any leadership. That attitude is just as futile as the church as a goal in itself. While those who opt for a high church replace the Kingdom with the institution, liberal and charismatic Christians only dwell in their religious feelings and impressions. They also forget that the message of Christ is about the Kingdom. Therefore some ministerial structure is needed in order to keep people to the calling of the church. The Spirit of God is not the free spirit of human beings, but the Spirit of Christ and his message of the Kingdom of God. Precisely therefore it cannot do without the form of the concrete earthly Jesus and his work, on the one hand, and the form of a ministry which is called to keep people to this message, on the other. 
The theological discourse that Noordmans followed from his early years as a student until his death in 1956 is most relevant for the $21^{\text {st }}$ century. It is critical of those who want a church as an influential and powerful institution in the world. It is also critical towards all who enjoy their liberal or charismatic feelings, but forget that the gospel is about the Kingdom of God. His view is a consolation for those who anxiously worry about the church and her future. The church can go, but God's Kingdom will come. The aim of the church is not to last. Her glory is not situated in the fact that she endures. The fact that she lasts is cause for guilt: it testifies to the fact that as yet her message has not been convincing, so that the Kingdom of God has not come. When the institutional church is under pressure, let her just consider that she does not have to survive, and let her proclaim the message of the Kingdom.

\subsection{Time and eternity}

It may seem that one could place Noordmans in the sphere of public theology. To a certain extent one could indeed call Noordmans a public theologian, but if so, he was a very peculiar one; in any case a very critical one. Like Barth once wrote: "Kritischer müssten mir die Historisch-Kritischen sein" (Barth 1922:xii), so one could describe Noordmans' position on public theology as: "The social critical theologians should be more critical."

Noordmans could also describe the poles of church and Kingdom in terms of time and eternity. The church belongs to time, and it will have its time as long as this world will last. The Kingdom, however, is eternal. The church is a temporal institution; the Kingdom is God's eternal Lordship. Therefore the church will decay, the Kingdom will be everlasting. One should not construe this relation as a temporal sequence: after time eternity will come. On the contrary, eternity does not belong to time and does not have an "after". Eternity is here and now, for it is a-temporal. In this sense Noordmans could say: "God makes his eternal decisions at the very last moment" (Noordmans 1949: p.110; VW 2: p.493). What God's eternal will is, is his will here and now. Eternity is not in the future after the consummation of the world, but it is the presence of God's will at this very moment. It is the critical message of the Kingdom in the kairos of the now; therefore, we cannot escape by postponing the calling of the Kingdom to the future. 
This does not mean that we can build the Kingdom here and now, as a contribution to its future consummation. At the very moment we do so, we are making forms. This is the risk of a public theology which has grasped the message of the Kingdom, but is not aware of its critical eschatological character. It confuses eschatology with future and eternity with time. Precisely because the church is about the eschatological Kingdom, she has no future - and the Kingdom also does not have a future as a temporal state of affairs. The message of the Kingdom is an ongoing critical appeal over against any human action, any human institution, and any human success.

Noordmans not only opposes theologians who plea for a strong institutional church, but also the church leadership of the Dutch Reformed Church after World War II which claimed the church should contribute to a new sustainable and just society (see esp. Noordmans, VW 5: p.520-557). They were inspired by Karl Barth's Christengemeinde und Bürgergemeinde (Barth 1946) and wanted to operate according to his ideas. The church would be the inspiring power for a just society. Noordmans compares this with the activities of a scouting group (Noordmans 1946a; $V W$ 5: p.524). It is very helpful for feeling good, but a far cry from the critical call of the Kingdom.

This call turns us away from time to eternity, away from our projects to God's acts. The Kingdom does not originate from our activities, but from our death. It breaks down all our claims and creates life where life was lost. Resurrection is totally different from immortality. People strive for everlasting projects and an everlasting just society. Motivated Christians see themselves as the forerunners of this project, despising those who lag behind. Such projects lead to self-satisfied people. They live by works and not by grace. The Kingdom of God proclaims grace for those who were lost and life for the dead. Therefore it is as critical of any project, any good intention, as it is of any good feeling and any institution. As it is eschatological, it places everything under critique. Therefore the church should always keep some distance from human institutions, plans and activities. According to Noordmans, she should practice some kind of ascesis, (Noordmans 1941a; 1934a: p.24-27; VW 2: p.228f). This precludes that Christians replace the present situation, which they rightly criticize, with their own projects and ideals, for these are also limited human projects at the expense of those of others. 


\subsection{Weak ascesis}

Ascesis is a core concept in Noordmans' theology. Ascesis can easily be misunderstood. It is precisely in the recovered article, that Noordmans makes very clear what he means by this concept. He distinguishes between weak and strong ascesis. Weak ascesis is turning your back on the world. It is the most common attitude towards this concept. Weak ascesis knows very well about the limitations of human activities and atrocities in human history. It also knows the world will not change for the better. We should not delude ourselves that in our time humankind will suddenly come of age and reject competition and war. Due to this correct conviction, those who practice weak ascesis just accept the world as it is and with a stoic or mystic attitude, leaving it to its own devices.

In the church, this weak ascesis can have several faces. Often it is related to mystic persons who enjoy God's presence deep in their heart. They live at the summits of love and joy in spite of a world full of suffering and injustice. Nothing that happens around them is relevant anymore, since they live in divine light. It can also be the ascesis of the monastery or similar religious groups, who in the enclosure of their community enjoy peace and unity, while the outside world continues in its evil ways.

Noordmans perceives weak ascesis also in the liturgical movement. The High Church conceives liturgy as a symbol of eternal reality. It is rightly aware of the temporal character of the church, but it thinks that there is some kind of symbolic divine presence in liturgy. It seems to be very respectful in its symbolic attitude. However, it excludes God from the world. It can celebrate a symbolic heavenly liturgy, while forgetting that God did not come down in beauty and light, but in the awful face of the Crucified One in the darkness of Calvary. Therefore, it lacks a sense of reality. A high liturgy is beautiful, but it signifies nothing: it is a symbol of reverence for a God who is not the God of the real world.

This does not mean that a Low Church liturgy can escape critique. It can even be more open to weak ascesis. In his critique, Noordmans focused especially on high liturgical forms, but if we contextualize his theology for the present, we should rather focus on Low Church liturgical expressions. In this sense Noordmans is most relevant today. Reformed churches and charismatic groups easily sing the praises of God, but forget harsh reality. In 
the words of a Dutch hymn: "Give me, Lord, to sing me free from the world and its struggle." (Liedboek voor de kerken, Gez. 475) It is precisely this that happens in many reformed congregations or in charismatic communities nowadays. They praise the Lord, not even mentioning the world and its suffering. It is pep song, stripped of any sense of reality, biblical reality most of all. The book of Chronicles tells us that David appointed Asaf, Heman, Jeduthun and Ethan as conductors of the temple choruses to praise the Lord (I Chron. 15: 19; 16:37, 41). Israel collected the greatest hits of these musicians in the book of Psalms. Among them are Ps. 39, 50, 62 and 73-89, which is about people who suffer. Therein one finds a person who almost lost his trust in God because of the injustice in the world, who complains that God does not help any more as He did in the past, and that the Lord seems to have forgotten the covenant with his servant David. These songs are, according to the Bible, the greatest songs in praise of God (see Van de Beek 2012: p.18-23). These songs portray reality.

One would be well advised to rather sing the old psalms instead of present songs of praise, which lack any sense of reality and make worship futile. The latter are an expression of weak ascesis and this makes the church irrelevant. It lacks not only a sense of reality, of what is going on in the world, but also a sense of the real God who was present in the world and cried: "My God, my God why have you forsaken me?" (Mk. 15:34, NIV) which echoes the reality of so many people. The true God of the world is himself in agony, as Noordmans (1941a) says - and so is his world.

\subsection{Strong ascesis}

The world is not a rose garden and its Creator is not a landlord in his domain. He is not to be found in the ecstasy of beauty or in the songs of praise with our backs turned to reality. "Creation is nothing but a circle of light around the cross", says Noordmans ( VW 2:209;1934a: p.54 = VW 2: p.245). That is reality. A good, strong ascesis recognises this. It sees reality from the perspective of the cross, which shows that reality is never perfect, not only as a fate to be borne by limited human beings, but it implies guilt. We try to construct forms in order to hide from this reality. We try to give the impression that we have succeeded. However, the cross unmasks our projects. Even our best works are stained with sin, as the Heidelberg Catechism (ans. 62) says, for everything in this world is criticized by the 
cross. It does not help to flee into a weak ascesis, for the songs of praise cannot deny our part in the unjust world. It does not help to keep us pure in a small community or deep in our hearts, for by condemning the impure world outside, we condemn ourselves due to our lack of compassion with broken humankind.

Strong ascesis is accepting critique and recognising that we ourselves are part of the problem. It is a critique which calls for conversion. Not the conversion of pious people who consequently feel better than the rest, but the conversion of the cross: participating in the sorrows and guilt of one another. If there is a real community in the world, it is a community of sinners.

This strong ascesis is the way the church expresses hope. It is highly relevant for the church today, also for the church in South Africa. It might help in the process of unification. This cannot be a mere institutional unification. It is the unity of people who know about conflicts and hard hearts, about exclusion and supremacy of all kinds and from all sides. In the light around the cross we are all sinners and are unified as sinners. We are saved, not by keeping to our positions or by building a solid church for a tenable society for the future, but by the One who was crucified and accepted sinners of all kinds. A strong ascesis is difficult, for it requires of us to abandon solid positions and traditional identities and to share in the unity of the one community of Christ.

The strong ascesis to which Noordmans refers, is also a way out of the chaos of present discussions about sexuality. Just like belonging to social communities, sexuality is one of the deepest markers of identity, maybe even more so. It is also the most characteristic marker of our lack of identity. We cannot hide in biological claims. Indeed, in biology male and female sexuality are not as fixed as many people claim in the discussion. We cannot hide in quoting a few Bible verses, since everybody knows that we do not keep to, and are not called to keep to, many biblical commandments. Strictly heterosexual persons are not free from the chaos of sexuality, any more than homosexuals are. Since we seek orientation, we hide our anxiety by condemning those who differ from the sexual forms we have created. Nobody can and will speak freely about all his or her sexual feelings and longings, and if somebody is inclined to do so, we feel aversion. A strong 
ascesis demands that we distance ourselves from our secure constructions where we hide our sexual chaos and accept others in the chaos of their own sexuality.

If we are honest we must confess that we do not know how to deal with sexuality. A weak sexual ascesis, as was called for in the church through celibacy, will not help, for indeed the monks and nuns also have sexual feelings. We can only accept each other, not because everybody is right and has his or her own right, but because nobody is right and no one can escape from the chaos inherent in humanity with regard to issues like sexuality, gender, greed, survival of the fittest. A strong ascesis entails losing ourselves as sinners even in our best works and convictions, and finding each other as sinners. This ascesis is the highest participation: the unity of human beings in the circle of light around the cross.

\section{Conclusion}

Ultimately, the church has no future, states Noordmans. The church will lose parts and ideas which were so dear to her, just like individual Christians in the progress of time do not gain but lose. Life is nothing but an ongoing dying. For a Christian it is most of all dying to the idea that we are the good ones and others the bad ones, or at least less good. It is learning about our vulnerability and the brokenness of life, which we share with other human beings - and with the God whom we remember in his agony and death on the cross.

\section{The text of Noordmans' article}

After this introduction and an indication of its relevance for the present, we give the full text of Noordmans' article in the translation of Dr. John Gavera. It is a challenging text, and we hope this text will challenge the readers to read more of the work of Noordmans.

Church and Future, by Dr. O. Noordmans

(Translated from the Dutch by Dr. J.P. Gavera) 
May God continue to bless country and nation.

Even amidst judgements we await Thee, o Lord.

Never lag in zeal.

Be fervent in spirit.

Serve the Lord.

Rejoice in hope.

Have patience in tribulations.

Be constant in prayer.

Awaiting the revelation of His everlasting Kingdom.

(Message of the Synod)

\section{Time and eternity}

It is very difficult to portray the future of the Church. To a certain extent, we can depict her relationship to things and institutions, which are encountered close to her in time, for instance the school and the state. As regards the future, however, it is quite a different matter. When we enquire after the future, it immediately becomes clear that the church belongs to another order altogether. For the future of the church involves no development, change or improvement of her present. Here present and future take on the meaning of time and eternity, so that one should think more in terms of the cessation rather than the continuation of the history of the church.

The future of Christ differs from that of all earthly things. It signifies his second coming. The church would not be church if, in this regard, her position was not special. According to the Bible, it is apparent that the future of the church depends upon the second coming of Christ. Initially, the apostles did not expect her to continue to exist for a long time. In any case, the stay of Christ's return is no reason for her to boast. That the church continues to exist is no honorific title for her, but rather the opposite. We forget that too easily. Thus we lament over that which should evoke our joy; and we rejoice over that which should arouse our sorrow. 
Indeed, we ought therefore to remind each other that the Bible admonishes us to focus our thoughts upon that which is above and not on that which is on earth. Our meditation on eternity must never cease. A church, which lags behind in this respect, may lose her sublimity of thought and see her love grow cold. We should therefore examine ourselves and ask whether we are still at the level where the church should be accustomed to stand, and whether we have also stopped "training" in this regard, as the Bible puts it. Previously, our nation had a rich literature on spiritual training, which has now become obsolete. Has it indeed been replaced by something to aid us in ascending "the steps of spiritual life"'? Have we not become somewhat careless in comparison to earlier generations, and also forgetful of the spiritual armour of which the apostle speaks ${ }^{2}$ ? Indeed, do we still know anything about that which the church used to call ascesis? On the low plain the church suffers defeat; only on the high ground can she hold her own ${ }^{3}$.

\section{Church and kingdom}

And yet, the church should exercise caution in her meditation on eternity. The word "eternity" has two meanings: a weak, silent one and a strong, active one. Last mentioned is the Biblical meaning. Therefore it is perhaps preferable to speak of "Church and Kingdom" instead of "time and eternity". The church is time full of grace, and the Kingdom is eternity full of power and glory. These two should be inseparably related. The training in godliness will then not remain a mere pious game of ideas, but become a bearing of the cross with good cheer and a strong resistance against the devil, the world, and our own flesh. I am not convinced that the church has always purely adhered to this. Her teaching concerning spiritual training sometimes had two roots: a weak, silent one; and a strong, active one. Formerly, that was also the case in ascetic pamphlets. One is frequently reminded of Vondel or Spinoza. The adage "Eternal precedes moment"4 never sounded fully Biblical.

1 Title of an ascetic booklet by Theodore à Brakel.

2 Ephesians 6.

3 Judges 1.

4 Translator's note: the Dutch text reads: "Eeuwig gaat voor oogenblik ". 
In the history of the church, however, the main trend was determined by the relationship between Church and Kingdom. Jesus also taught us to pray: hallowed be Thy Name; Thy Kingdom come; Thy will be done in earth as it is in heaven. The Kingdom-prayers immediately take precedence in the Lord's Prayer. The prayers for grace, and the prayers for the church only follow thereafter. So, too, in the Bible, the Gospels, which describe how the Kingdom of heaven came near, are followed by the book of the Acts of the Apostles, which tells of the origins of the church.

The reverse is not stated in Scripture. We do not read that the church changes into the Kingdom. The book of Revelation does indeed come at the end, but that has to do with the return of Christ, the future of Christ; not the future of the church in the ordinary sense of the word. The future of Christ implies that He comes to us. Come, Lord Jesus! is the resounding supplication at the end of the book.

\section{Church and future}

The future of the church is thus not written with a capital letter. She does not believe that if only she can endure long enough, the Kingdom of God will automatically be born from her. The Kingdom must come of itself. It has come and it comes and it shall come, because it is an eternity of powers. At times men thought, or indeed still think, that the Kingdom will be the product of the church. God's governance of grace would gradually change into the revelation of His glory. The theology of the cross would in course be relieved by a theology of glory. Scripture gives the lie to such thoughts, and experience disproves them. We do not read, and perceive even less, that it could be so.

The future of the church itself has nothing divine about it. Nowhere in the Bible, or in the church, do things simply come right over time. No living church exists that has thus far escaped the law of death; there will also never be such a church.

One should rather say that time presupposes God's long-suffering patience. Repeatedly it is said: Allow it to stand one more year! In this regard, God is far more patient than His prophets, and Jesus than His disciples. In herself the church has no guarantee of her continued existence. She may and must also expect God in the way of His judgements. A mystic immortality, 
godlike, she does not possess. She has life not in herself, but in Christ. It is not true that she is like Lot's wife, who as a pillar of salt, it is said, continually renews her form, so that a hand broken off replaces itself. Such church deification is unbiblical. There are parts of the church that can fall away and which we shall never see returning in this time. It happens with her as with every believer. She will have to be disrobed of her future and be clothed with the future of Christ.

\section{Enduring or praying}

Therefore, the power of the church does not lie hidden in her enduring existence, but in her praying. The enduring of the church is a type of deathbed; an agony. Her praying is breathing. She does not actually think about her future; but indeed about the return of Christ. In any case, the former affords her little, the last an inexpressible consolation. In expectation of that she must serve, rejoice, be patient, persevere, and wait. These things cannot be delayed, even less be postponed. That happens when one has placed one's hope on enduring. Praying and working belong together.

The church always carries her future with her. The kingdom of heaven has drawn near. Everything that happens in the church happens under the influence of that nearness. The true church arises daily from the impact of the Kingdom upon her. She cannot cash in on eternity. Eternity does the reverse with her. It is exactly that which endangers her duration and teaches her to cry out: Pray for us and teach us how to pray. ${ }^{5}$

Thus, the contact with the Kingdom continually creates new power outlets in the church. Faith conquers the world. Love is stronger than death. Regeneration is a new creation. They give the church an existence, which for us is incalculable. There is no power by which these forces can be taught or learnt. ${ }^{6}$ They will be there as long as God is there, even if it seems that

5 The Chinese Christians at Tambaran.

6 The Dutch reads: "Er is geen macht, die deze werkingen kan leeren." "Leren" might be a typo for "keren" (resist), which seems to give the sentence a clearer meaning. An 1 and a k can easily be confused, even more so if one takes into consideration that Noordmans probably submitted a handwritten text. On the other hand, though there are some typo's in the reprint (1941b), the version "leren" is in both texts. Noordmans often has turns of phrases which are not obvious. It is known that he could stand at the window for a whole morning just thinking about the right formulation of one sentence. 
they imperil the church. In no other way is there any certainty available for us.

\section{Symbol and reality}

The future of the church lies firmly in the fullness of reality. She can take the liberty to be realistic. In that she has nothing to lose, but everything to gain. She may and she must look things fully in the face. God is the creator of heaven and earth, and the church cannot distance herself from matters that are put in motion in this way. These are daily matters with which she is faced. In the Lord's Prayer, the prayer for the daily bread immediately follows after the kingdom-prayers. Then follow the trespasses which we multiply every day.

The church must keep to this order of things. In this way she is firmly bound to the present. She may not omit this in order to become involved with a future and provide herself with an own duration. The daily bread is meant for the present. The grace of the forgiveness of sin is a present grace. The opportunities of the church lie in the present, because it is there that she has contact with the kingdom of God. Nowhere is there so little delay as in the Gospel. Even in his death, with His words from the cross to the murderer, Jesus took the present with Him.

Now the temptation is still great that the church will digress from this attitude towards reality by focusing on the symbol of which she deems herself to be the custodian. In this way she seems to bestow the highest honour upon the reality with which she has to contend by declaring it a mystery that can only be depicted symbolically because it transcends all understanding. In reality it is the most refined way in which the church seeks to provide herself with a duration of her own making. For the church as symbol-custodian escapes the dangerous contact with the kingdom of

So it might be that he indeed meant "leren". This would correspond with the preceding word "onberekenbaar" (incalculable). In Dutch "leren" can mean either teach or learn. Thus, one cannot teach or learn the power of the Kingdom, nor train people to become good participants in it, or even learn to do so ourselves. The Kingdom is a gift from God which cannot be manipulated, either by teaching others or by learning ourselves (AvdB.). 
God and gains the opportunity to endure under the semblance of worship (Dutch reads: ((aan)bidden).

In a very special way the reality which the church has to face does not transcend her understanding. Everyone hears it mentioned in his own tongue: it is the daily matters that he encounters in the present. Of that the church has enough understanding to know that in this world a cross that threatens her own future may stand ready for her. She must deny herself, take up her cross, and follow Jesus.

In that way she focuses on her true future, which God has laid aside for her: the future of Christ, His return. She longs to meet the "Lord, all powerful".?

She does not wish to extend her own duration, but prays the meeting will take place with haste. Until then she already lives in the dangerous zone of the contact with the kingdom, from which her wonderful history originated.

\section{Bibliography}

Barth, K. (1922) Der Römerbrief. München: Kaiser.

(1946) Christengemeinde und Bürgergemeinde. Theologische Studien 20. Zollikon/Zurich: Evangelischer Verlag.

Liedboek voor de kerken. (1973) Zoetermeer: Boekencentrum.

Noordmans, O. (1892) Het kerkbegrip als achtergrond van de kerkorde. VW 10. p. 64-66.

- (1934a) Herschepping: beknopte dogmatische handleiding voor godsdienstige toespraken en besprekingen. Nederlandsche ChristenStudenten-Vereeniging, Zeist (2e ed. in VW 2. p.214-322).

- (1934b) De dubbelzinnigheid van het leven: Romeinen 7: 14-25. In Molenaar P. J. (ed.). Psychologie en Evangelie. Amsterdam: Uitgeversmaatschappij Holland. p.38-66 (= Psychologie en Evangelie: Romeinen 7: 14-25. VW 2. p.98-118).

7 The Dutch reads: "Heer, vol krachten". According to Noordmans it refers to the rhymed version of Psalm 147:3. 
- (1946a) Kerk of beweging. Orgaan Bond Nederlandse Predikanten 23

(2) (= VW 5. p.520-525).

- (1946b) Zondaar en bedelaar. Amsterdam: Uitgeversmaatschappij Holland (= VW 8. p.13-100).

- (1941a) Kerk en toekomst. Weekblad van de Nederlandsche Hervormde Kerk 25 (10). p.51-52.

- (1941b) Kerk en toekomst. Hervormd Amsterdam.

- (1949). Het Koninkrijk der hemelen: Toelichting op de Heidelbergse Catechismus zondag 7-22. Nijkerk: Callenbach (= VW 2. p.433-551).

- (1956) Gestalte en Geest. Amsterdam: Uitgeversmaatschappij Holland (= VW 8. p.179-478).

(1978-2004) VW. Verzamelde werken 1-10. Kampen: Kok.

Van de Beek, A. (1991) Fundamentalisme: excentriciteit en soliditeit van de geloofsgrond. In: Boele van Hensbroek, P. e.a. (eds.). Naar de letter: Beschouwingen over fundamentalisme, Utrecht: Grafiet. p.17-40.

(2012) Hasselelponi: Meditaties over verrassende teksten uit de Bijbel. Zoetermeer: Meinema. 